Dedicated to Prof. Billy E. Rhoades on the occasion of his $90^{\text {th }}$ anniversary

\title{
Frum-Ketkov operators which are weakly Picard
}

\section{Adrian PETRUŞEL ${ }^{1,2}$, IOAN A. RUS ${ }^{1}$ and MARCEL-AdRIAN ŞERBAN ${ }^{1}$}

\section{ABSTRACT.}

Let $(M, d)$ be a metric space, $X \subset M$ be a nonempty closed subset and $K \subset M$ be a nonempty compact subset. By definition, a continuous operator $f: X \rightarrow X$ is said to be a Frum-Ketkov operator if there exists $l \in] 0,1[$ such that $d(f(x), K) \leq l d(x, K)$, for every $x \in X$. In this paper, we will give sufficient conditions ensuring that a Frum-Ketkov operator is weakly Picard. Some generalized Frum-Ketkov operators are also studied.

\section{REFERENCES}

[1] Berinde, V., Iterative Approximations of Fixed Points, Springer Berlin, 2007

[2] Binh, T. Q., Some extensions of contractive mappings, Nonlinear Funct. Anal. Appl., 9 (2004), No. 4, 659-677

[3] Browder, F. E., Nonlinear operators and nonlinear equations of evolutions, Proc. Sympos. Pure Math., 18 (1976), Part 2

[4] Buley, H., Fixed point theorems of Rothe-type for Frum-Ketkov and 1-set-contractions, Comment. Math. Univ. Carol., 19 (1978), No. 2, 213-225

[5] Diaz, J. B. and Metcalf, F. T., On the set of subsequential limit points of successive approximations, Trans. Amer. Math. Soc., 135 (1969), 459-485

[6] Edelstein, M. and O'Brien, R. C., Nonexpansive mappings, asymptotic regularity and successive approximations, J. London Math. Soc., 17 (1978), 547-554

[7] Frum-Ketkov, R. L., Mapping into a sphere of a Banach space (Russian), Dokl. Akad. Nauk SSSR, 175 (1967), 1229-1231

[8] Granas, A. and Dugundji, J., Fixed Point Theory, Springer, Berlin 2003

[9] Huang, J.-C., Common fixed points of asymptotically hemicontractive mappings, Indian J. Pure Appl. Math., 33 (2002), No. 12, 1811-1825

[10] Jiménez López, V., Kupka, J. and Linero, A., On the $\omega$-limit sets of product maps, Dynamic Systems and Appl., 19 (2010), 667-679

[11] Metcalf, F.T. and Rogers, T. D., The cluster setr of sequences of successive approximations, J. Math. Anal. Appl., 31 (1970), 206-212

[12] Nussbaum, R. D., The fixed point index and fixed point theorems for $k$-set-contractions, Ph.D. Dissertation, Univ. of Chicago, 1964

[13] Nussbaum, R. D., Some asymptotic fixed point theorems, Trans. Amer. Math. Soc., 171 (1972), 349-375

[14] Park, S. and Kim, W. K., On the Frum-Ketkov type fixed point theorems, Bull. Korean Math. Soc., 20 (1983), No. $1,5-8$

[15] Petryshyn, W. V. and Williamson, T. E., Strong and weak convergence of sequence of successive approximations for quasi-nonexpansive mappings, J. Math. Anal. Appl., 43 (1973), 459-497

[16] Rhoades, B. E., Contractive definitions revisited, Contemporary Math., 21 (1983), 189-205

[17] Roux, D. and Soardi, P., Sui punti uniti di mappe continue di una spazio topologico in se, Rev. Mat. Univ. Parma, 12 (1971), 21-28

[18] Rus, I. A., Fixed Point Structure Theory, Cluj Univ. Press Cluj-Napoca, 2006

Received: 24.02.2020; In revised form: 03.06.2020; Accepted: 10.06.2020

2010 Mathematics Subject Classification. 47H10, 54H25, 47H09.

Key words and phrases. metric space, asymptotic regular operator, contractive operator, quasinonexpansive operator, fixed point, fixed point structure, Frum-Ketkov operator, Buley pair, weakly Picard operator.

Corresponding author: I. A. Rus; iarus@math.ubbcluj.ro 
[19] Rus, I. A., Five open problems in fixed point theory in terms of fixed point structures (I): singlevalued operators, Fixed Point Theory and Its Applications (Espinola, R., Petruşel, A., Prus, S. - Eds.), Proc. 10th ICFPTA Cluj-Napoca, House of the Book of Science Cluj-Napoca, 2012, 39-60

[20] Rus, I. A., Relevant classes of weakly Picard operators, Annals West Univ. Timişoara Mat.-Inf., 54 (2016), No. 2, 3-19

[21] Rus, I. A., Remarks on s LaSalle conjecture on global asymptotic stability, Fixed Point Theory, 17 (2016), 159-172

[22] Rus, I. A., Convergence results for fixed point iterative algorithms in metric spaces, Carpathain J. Math., 35 (2019), No. 2, 209-220

[23] Rus, I. A., Petruşel, A. and Petruşel, G., Fixed Point Theory, Cluj University Press Cluj-Napoca, 2008

[24] Rus, I. A. and Şerban, M. A., Basic problems of the metric fixed point theory and the relevance of a metric fixed point theorem, Carpathian J. Math., 29 (2013), No. 2, 239-258

[25] Schöneberg, R., Some fixed point theorems for mappings satisfying Frum-Ketkov conditions, Comment. Math. Univ. Carol., 17 (1976), No. 2, 399-411

${ }^{1}$ Department of Mathematics

BABEŞ-BOLYAI UNIVERSITY CLUJ-NAPOCA, ROMANIA

${ }^{2}$ ACADEMY OF ROMANIAN SCIENTISTS, BUCHAREST, ROMANIA

Email address: petrusel@math.ubbcluj.ro

Email address: iarus@math.ubbcluj.ro

Email address: mserban@math.ubbcluj.ro 